\title{
Squamous cell carcinoma in situ arising in mature cystic teratoma of the ovary: a case report
}

\author{
Fatima A Zakkouri ${ }^{*}$, Saloua Ouaouch ${ }^{1}$, Saber Boutayeb ${ }^{1}$, Mouna Rimani ${ }^{2}$, Lamiae Gamra ${ }^{2}$, Hind Mrabti $^{1}$ and \\ Hassan Errihani ${ }^{1}$
}

\begin{abstract}
Introduction: Malignant transformation is a rare complication of mature cystic teratoma with squamous cell carcinoma being the most common type. We report a new case of squamous cell carcinoma in situ.
\end{abstract}

Case presentation: A 62 year old woman was admitted for an abdomino-pelvic mass and she underwent a left salpingo-oophorectomy. The histopathologic analysis revealed a squamous cell carcinoma in situ arising in mature cystic teratoma of the ovary. Then, she underwent a total hysterectomy, contralateral salpingo-oophorectomy and omentectomy without adjuvant treatment.

Conclusion: Optimal cytoreduction has been associated with a statistically significant improvement in survival for malignant transformation of mature cystic teratoma.

\section{Introduction}

Mature cystic teratoma (MCT) is the most common germ-cell tumor of the ovary. It consists of well-differentiated derivatives of the three germ-cell layers [1]. Malignant transformation is a rare complication of this pathology; it accounts for $1-2 \%$ of MCTs and the prognosis of this disease is generally poor [2]. In this article, we report a case of MCT who was admitted to National Institute of Oncology in Rabat (Morocco). The diagnosis was proved by histopathologic analysis.

\section{Case report}

A 62 year old woman was admitted to a gynecology clinic for adnexal mass which was suspected at first to be a MCT. She had only an abdomino-pelvic pain. Abdominal computed tomography scan revealed a heavily triple tissular mass with greasy and osseous constituent $(=10 \mathrm{~cm})$ (Figure 1$)$. The serum tumour markers (BHCG, AFP and LDH) were normal. The patient underwent a laparotomy who revealed a voluminous abdomino-pelvic mass. She underwent a left salpingooophorectomy only. The histopathologic analysis

\footnotetext{
* Correspondence: zora-83@hotmail.com

'Department of Medical Oncology, National Institute of Oncology, Rabat, Morocco

Full list of author information is available at the end of the article
}

revealed a squamous cell carcinoma in situ arising in mature cystic teratoma of the ovary (Figure 2 and 3 ).

Then she was referred to our institution for treatment. Pelvic examination, thoraco-abdominal computed tomography scan and the serum tumour markers (BHCG, AFP, LDH and CA125) were normal. She underwent a total hysterectomy, contralateral salpingo-oophorectomy and omentectomy.

The histological examination found a mature cystic teratoma in the contralateral ovary without malignant transformation. Adjuvant treatment was not planned.

\section{Discussion}

Ovarian germ-cell tumours account for around 20-25\% of ovarian neoplasms and $5 \%$ of cancers of the ovary [3]. Mature cystic teratoma (MCT) is the most common ovarian germ cell tumor (10-20\% of all ovarian tumors) [1]. Malignant transformation of mature cystic teratomas is very rare (1-2\%), with squamous cell carcinoma being the most common type [4]. Pure squamous cell carcinoma in situ arising in an ovarian cystic teratoma is extremely rare [5]. We have only 5 cases from 1976 to 2005 [6].

In our case, it's a squamous cell carcinoma in situ arising in ovarian mature cystic teratoma. In most of the series, the median age at diagnosis of malignant transformation of MCT was 54-61.5 years [7] and the most common symptoms were abdominal pain, palpable mass 


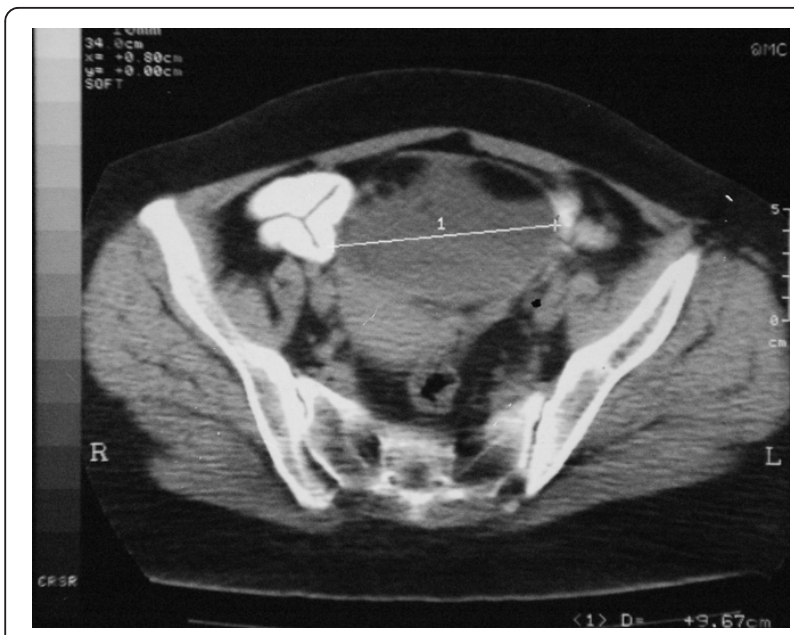

Figure 1 Abdominal computed tomography scan: a heavily triple tissular mass with greasy and osseous constituent $(=10 \mathrm{~cm})$.

and abdominal distension; but some people may be asymptomatic at diagnosis [8]. MCT with diameter $>10 \mathrm{~cm}$ is associated with increased risk of malignancy in some studies [9]. In our case, the tumor size was $10 \mathrm{~cm}$. Most of studies have found that MCT has a poor prognosis. Early stage and optimal cytoreductive surgery are reported to be good prognostic factors [10].

Due to the relative rarity of the squamous cell carcinoma in situ arising in MCT, there is no uniform consensus regarding treatment. However, the treatment for many authors consist to a complete tumor excision. Adjuvant chemotherapy or radiotherapy is not helpful in improving survival [4-6].

In the review of the literature from 1976 through to 2005 , the optimal debulking rate for carcinoma in situ was $100 \%$ and the 5 -year survival rate for this disease was $100 \%$ [6].

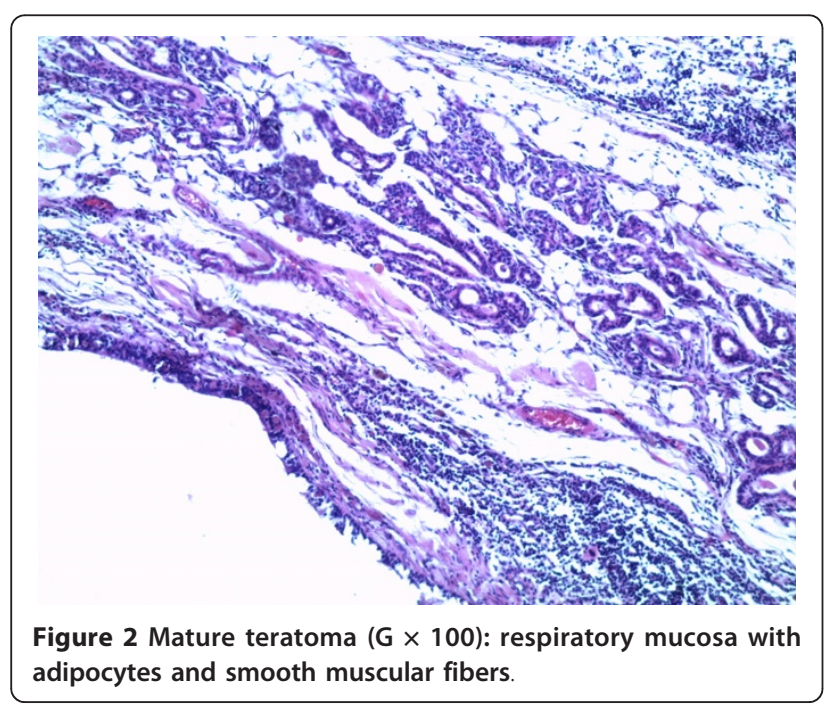

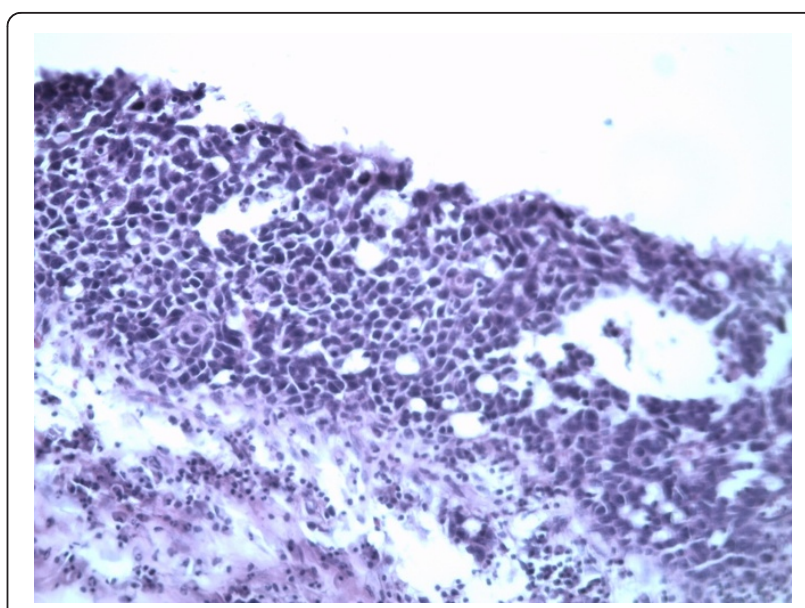

Figure 3 Squamous cell carcinoma in situ $(G \times 300)$ : Atypical cells on all the epithelial height with an architectural disorganization. The basal membrane is intact and the chorion is free.

\section{Conclusion}

Squamous-cell carcinoma in situ arising in a mature cystic teratoma is an unusual disorder. Because of the rarity of this disease, there is no therapeutic standard at the moment. However, the prognosis seems highly dependent on complete surgical debulking.

\section{Consent statement}

written informed consent was obtained from the patient for publication of this case report and accompanying images.

\section{Abbreviations}

MCT: Mature cystic teratoma; BHCG: B-human gonadotropin; AFP: afetoprotein; LDH: lactate dehydrogenase.

\section{Author details}

'Department of Medical Oncology, National Institute of Oncology, Rabat, Morocco. "Laboratory of Histopathology "Hassan", Rabat, Morocco.

\section{Authors' contributions}

FAZ: participated in the care of the patient and wrote the article. SO: participated in the care of the patient. SB: participated in the writing of article. MR and LG: realized the histopathologic analysis. HM: participated in the writing of article. HE: Validated content and form of the article. All authors read and approved the final manuscript.

\section{Competing interests}

The authors declare that they have no competing interests.

Received: 23 December 2010 Accepted: 24 March 2011 Published: 24 March 2011

\section{References}

1. Stern JL, Buscema J, Rosenshein NB, Woodruff JD: Spontaneous rupture of benign cystic teratomas. Obstet Gynecol 1981, 57:363-6.

2. Peterson WF, Prevost EC, Edmunds FT, Hundley JM Jr, Morris FK: Epidermoid carcinoma arising in a benign cystic teratoma; a report of 15 cases. Am J Obstet Gynecol 1956, 71:173-89.

3. Hackethal Andreas, Brueggmann Doerthe, Michael KBohlmann, Folker EFranke, Tinneberg Hans-Rudolf, Karsten Münstedt and co: Squamous-cell carcinoma 
in mature cystic teratoma of the ovary: systematic review and analysis of published data. Lancet Oncol 2008, 9:1173-80

4. Dos Santos Lisa, Mok Evelyn, Alexia lasonos, Kay Park, Soslow ARobert, Carol Aghajanian and co: Squamous cell carcinoma arising in mature cystic teratoma of the ovary: a case series and review of the literature. Gynecologic Oncology 2007, 105:321-324.

5. Dadhwal V, Sarkar SK, Arora V, Mittal S: Squamous cell carcinoma in situ arising in mature cystic teratoma. Indian J Pathol Microbiol 2002, 45(3):345-6.

6. Chen Ruey-Jien, Chen Ko-Yang, Chang Ting-Chen, Sheu Bor-Ching, Chow Song-Nan, Huang Su-Cheng: Prognosis and Treatment of Squamous Cell Carcinoma from a Mature Cystic Teratoma of the Ovary. J Formos Med Assoc 2008, 107(11).

7. Dos Santos L, Mok E, lasonos A: Squamous cell carcinoma arising in mature cystic teratoma of the ovary: a case series and review of the literature. Gynecol Oncol 2007, 105:321-4.

8. Tseng CJ, Chou HH, Huang KG, Chang TC, Liang CC, Lai CH and co: Squamous cell carcinoma arising in mature cystic teratoma of the ovary. Gynecol Oncol 1996, 63:364-70.

9. Yamanaka $\mathrm{Y}$, Tateiwa $\mathrm{Y}$, Miyamoto $\mathrm{H}$, Umemoto $\mathrm{Y}$, Takeuchi $\mathrm{Y}$, Katayama $\mathrm{K}$ and co: Preoperative diagnosis of malignant transformation in mature cystic teratoma of the ovary. Eur J Gynaecol Oncol 2005, 26:391-2.

10. Park Jeong-Yeol, Kim Dae-Yeon, Kim Jong-Hyeok, Kim Yong-Man, Kim Young-Tak, Nam Joo-Hyun: Malignant transformation of mature cystic teratoma of the ovary: Experience at a single institution. European Journal of Obstetrics \& Gynecology and Reproductive Biology 2008, 141:173-178.

doi:10.1186/1757-2215-4-5

Cite this article as: Zakkouri et al:: Squamous cell carcinoma in situ arising in mature cystic teratoma of the ovary: a case report. Journal of Ovarian Research 2011 4:5.

\section{Submit your next manuscript to BioMed Central and take full advantage of:}

- Convenient online submission

- Thorough peer review

- No space constraints or color figure charges

- Immediate publication on acceptance

- Inclusion in PubMed, CAS, Scopus and Google Scholar

- Research which is freely available for redistribution

Submit your manuscript at www.biomedcentral.com/submit 